\section{Commentary: Not just for kids anymore: The Ross procedure grows up}

\author{
Joseph S. Coselli, MD
}

Contemporary aortic valve replacement (AVR) is a common and relatively simple procedure that is broadly performed across numerous centers; operative risk is largely dependent on patient health, with operative mortality nearing $1 \%$ in low-risk elective patients. ${ }^{1}$ The Ross procedure relies on substituting the diseased aortic valve with a pulmonary autograft that is in turn replaced by a homograft conduit within the right ventricular outflow tract. ${ }^{2}$ Most often, this procedure is performed as a full root replacement. Aortic root replacement (ARR) is more complex and performed far less frequently than isolated AVR, with operative mortality approaching $3 \%$ in elective patients. ${ }^{3}$ A recent analysis of the Society of Thoracic Surgeons database found that the Ross procedure was the least common type of ARR, accounting for $0.9 \%$ of elective repairs. ${ }^{3}$ Traditionally, the Ross procedure has been relegated to use in pediatric populations, but recently this approach has seen a resurgence in use that is primarily centered on young and middle-aged adults. ${ }^{2,4}$ The promise of the Ross approach is superb hemodynamic parameters and freedom from anticoagulation offered by this tissue-based option for repair; the demise of this approach is the result of well-established concerns of durability. ${ }^{7}$

From the Division of Cardiothoracic Surgery, Michael E. DeBakey Department of Surgery, Baylor College of Medicine; Department of Cardiovascular Surgery, Texas Heart Institute; and CHI St Luke's-Baylor St Luke's Medical Center, Houston, Tex.

Supported in part by an endowment from the Cullen Foundation.

Disclosures: Dr Coselli consults for, receives royalties and a departmental educational grant from, and participates in clinical trials for Terumo Aortic; consults and participates in clinical trials for Medtronic, Inc, and W.L. Gore \& Associates; and serves as a coinvestigator for CytoSorbents.

The Journal policy requires editors and reviewers to disclose conflicts of interest and to decline handling or reviewing manuscripts for which they may have a conflict of interest. The editors and reviewers of this article have no conflicts of interest

Received for publication Dec 2, 2020; revisions received Dec 2, 2020; accepted for publication Dec 3, 2020; available ahead of print Dec 16, 2020.

Address for reprints: Joseph S. Coselli, MD, Division of Cardiothoracic Surgery, Michael E. DeBakey Department of Surgery, Baylor College of Medicine, One Baylor Plaza, BCM 390, Houston, TX 77030 (E-mail: jcoselli@bcm.edu).

J Thorac Cardiovasc Surg 2021;161:916-7

$0022-5223 / \$ 36.00$

Copyright (c) 2020 by The American Association for Thoracic Surgery

https://doi.org/10.1016/j.jtcvs.2020.12.032

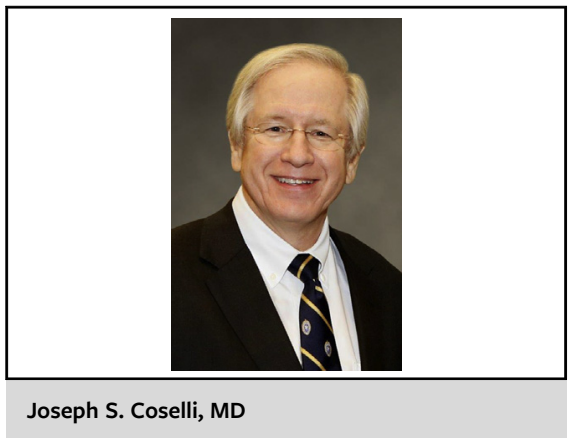

\section{CENTRAL MESSAGE \\ Should we be expanding the use \\ of Ross procedure in adults? \\ Outstanding early results can be \\ achieved by expert hands in \\ select patients.}

Stelzer and colleagues ${ }^{8}$ from the Icahn School of Medicine at Mount Sinai present their extensive single-surgeon experience (from 1987 to 2019) with the Ross procedure in more than 700 patients. ${ }^{8}$ The vast majority of repairs involved adult patients (mean age, 42 years), many of whom had bicuspid or unicuspid aortic valves, with aortic valve dysfunction roughly split between stenosis $(48 \%)$ and regurgitation $(45 \%)$. Most remarkably, over this $32-$ year time period, the authors had only 7 operative deaths, resulting in a mortality rate of $<1 \%$. The authors describe technical refinement over time, such as the use of felt strips and residual aortic wall to support the root's sinotubular junction. Furthermore, the authors describe a shift over time toward more complex repairs (eg, redo sternotomy, repair with additional replacement of the ascending aorta, and concomitant mitral valve repair) that was without any increased operative risk. The authors focus their report on early outcomes, without notable differences regarding surgical era or complexity. Echocardiography performed at discharge indicated a large percentage $(27 \%)$ of patients had mild or greater autograft regurgitation.

Without doubt, Stelzer and colleagues ${ }^{8}$ have tamed the Ross procedure. In their hands, this more complex repair has a risk similar to the simpler AVR procedure. But, there remain lingering concerns. One is how to train the next generation of surgeons to successfully perform this infrequently encountered approach. The authors suggest building experience with other forms of ARR until expertise can be achieved with 75 to 100 Ross procedures. ${ }^{8}$ However, this may prove elusive because nearly all forms of ARR are 
seldom encountered. ${ }^{1,3}$ Second, questions of durability must be probed elsewhere. In a study of 212 patients undergoing the Ross procedure, David ${ }^{6}$ found the cumulative probability of reoperation was $12 \%$ for the pulmonary autograft and $8 \%$ for the homograft conduit at 20 years, along with a time-dependent development of moderate or greater aortic regurgitation; moreover, his data suggest an enhanced risk of late endocarditis in the homograft conduit $(\mathrm{n}=7$, compared with none in the pulmonary autograft). A recent meta-analysis of both pediatric and adult patients undergoing the Ross procedure identified late structural valve deterioration of both the pulmonary autograft and the homograft conduit within the right ventricular outflow tract. ${ }^{9}$ This deterioration was age-dependent, and although nearly all children $(94 \%)$ can expect late reintervention because of autograft degeneration, only $32 \%$ of 55 -year-old patients were estimated to need late reintervention. For the homograft conduit, reintervention was estimated at $100 \%$ in children and only $14 \%$ in 55 -year-old adults. These findings, combined with the excellent outcomes of Stelzer and colleagues, ${ }^{8}$ may help shift repair from children to select adults, especially in light of emerging transcatheter valvein-valve applications that may provide an option for late reintervention. Although the exceptional volume of Ross procedures (more than 700 repairs) conducted by Stelzer and colleagues ${ }^{8}$ will no doubt make a substantial contribution to the literature, readily cementing the feasibility of this complex procedure, the key question of durability remains unanswered.

\section{References}

1. Ghoreishi M, Thourani VH, Badhwar V, Massad M, Svensson L, Taylor BS, et al Less-invasive aortic valve replacement: trends and outcomes from the STS database. Ann Thorac Surg. August 21, 2020 [Epub ahead of print].

2. Stelzer P. The Ross procedure: state of the art 2011. Semin Thorac Cardiovasc Surg. 2011;23:115-23

3. Hemli JM, Scheinerman SJ, Lesser ML, Ahn S, Mihelis EA, Jahn LA, et al. Transfusion in elective aortic root replacement: analysis of the STS adult cardiac surgery database. Ann Thorac Surg. 2020;110:1225-33.

4. Buratto E, Konstantinov IE. Aortic valve surgery in children. J Thorac Cardiovasc Surg. August 20, 2020 [Epub ahead of print].

5. Chauvette V, Bouhout I, Tarabzoni M, Wong D, Bozinovski J, Chu MWA, et al, The Ross procedure in patients older than 50: a sensible proposition? J Thorac Cardiovasc Surg. October 6, 2020 [Epub ahead of print].

6. David TE, Ouzounian M, David CM, Lafreniere-Roula M, Manlhiot C. Late results of the Ross procedure. J Thorac Cardiovasc Surg. 2019;157:201-8.

7. Ouzounian M, Mazine A, David TE. The Ross procedure is the best operation to treat aortic stenosis in young and middle-aged adults. J Thorac Cardiovasc Surg. 2017; $154: 778-82$

8. Stelzer P, Mejia J, Varghese R. Operative risks of the Ross procedure. J Thorac Cardiovasc Surg. 2021;161:905-15.e3.

9. Etnel JRG, Grashuis P, Huygens SA, Pekbay B, Papageorgiou G, Helbing WA, et al. The Ross Procedure: a systematic review, meta-analysis, and microsimulation. Circ Cardiovasc Qual Outcomes. 2018;11:e004748. 